\title{
Processing Strategies to Inactivate Enteric Viruses in Shellfish
}

\author{
Gary P. Richards ${ }^{1,{ }^{*}}$, Catherine McLeod ${ }^{2}$ and Françoise S. Le Guyader ${ }^{3}$ \\ ${ }^{1}$ U.S. Department of Agriculture, Agricultural Research Service, Microbial Food Safety Research Unit, Delaware \\ State University, Dover, DE 19901, USA \\ ${ }^{2}$ South Australian Research and Development Institute, GPO Box 397, Adelaide, South Australia 5001, Australia \\ ${ }^{3}$ Laboratoire de Microbiologie, Centre de Nantes, IFREMER, Rue de L'Ile O'yeu, B.P. 21105, 44311 Nantes \\ Cedex 03, France \\ *: Corresponding author : Gary P. Richards, email address : gary.richards@ars.usda.gov
}

\begin{abstract}
:
Noroviruses, hepatitis A and E viruses, sapovirus, astrovirus, rotavirus, Aichi virus, enteric adenoviruses, poliovirus, and other enteroviruses enter shellfish through contaminated seawater or by contamination during handling and processing, resulting in outbreaks ranging from isolated to epidemic. Processing and disinfection methods include shellfish depuration and relaying, cooking and heat pasteurization, freezing, irradiation, and high pressure processing. All the methods can improve shellfish safety; however, from a commercial standpoint, none of the methods can guarantee total virus inactivation without impacting the organoleptic qualities of the shellfish. Noroviruses cause the majority of foodborne viral illnesses, yet there is conflicting information on their susceptibility to inactivation by processing. The inability to propagate and quantitatively enumerate some viral pathogens in vitro or in animal models has led to the use of norovirus surrogates, such as feline calicivirus and murine norovirus. During processing, these surrogates may not mimic the inactivation of the viruses they represent and are, therefore, of limited value. Likewise, reverse transcription-PCR has limited usefulness in monitoring processing effectiveness due to its inability to identify infectious from inactivated viruses. This article (a) describes mechanisms of virus uptake and persistence in shellfish, (b) reviews the state-of-the-art in food processing strategies for the inactivation of enteric viruses in shellfish, (c) suggests the use of combined processing procedures to enhance shellfish safety, (d) highlights limitations in research data derived from virus surrogate studies and molecular assay procedures, and (e) recommends enhanced funding for human volunteer studies and the development of assays to detect viable viruses.
\end{abstract}

Keywords: Shellfish - Processing - Norovirus - Hepatitis A virus - Depuration - High pressure - Heat inactivation 


\section{Introduction}

Among the enteric viruses, the human noroviruses (NoV) and hepatitis $A$ virus (HAV) represent significant obstacles to shellfish safety. Both viruses are transmitted by the fecal-to-oral route and are found in sewage effluents. Consequently, ineffective sewage treatment systems and the introduction of raw sewage from residential or commercial facilities into waterways, which affect shellfish beds, pose a serious threat of shellfish contamination. Other viruses, like hepatitis E virus, astrovirus, rotavirus, sapovirus, and Aichi virus, are of lesser impact to the shellfishery, but have been associated with outbreaks of shellfish-associated illness (Cacopardo et al. 1997; Tomar et al. 1998; Le Guyader et al. 2008; Nakagawa-Okamoto et al. 2009). In spite of advances in our understanding of shellfish processing techniques, much more research is needed to define conditions that are effective for the inactivation of wild-type, pathogenic viruses, while ensuring preservation of the organoleptic characteristics that make shellfish so desirable. This paper provides information on some of the processing interventions that may be used to reduce or eliminate infectious viruses in shellfish. Most of these techniques have been evaluated using surrogate viruses, since some pathogenic viruses cannot be propagated in cell culture assay systems. Such is the case for the human NoV, for which infectious viruses cannot be quantified and where virus inactivation studies have relied on the use of feline calicivirus (FCV), murine norovirus-1 (MNV-1), and to a lesser extent poliovirus type 1 (PV), HAV, and bacteriophage as potential surrogates (Doultree et al. 1999; Dawson et al. 2005; Bae and Schwab 2009; Kingsley et al. 2002; Cannon et al. 2006; Hewitt et al, 2009; Belliot et al. 2008; Nuanualsuwan et al. 2002). Studies using surrogate viruses have limited value, as will be discussed. Likewise, most wild-type HAV cannot be readily propagated in cell culture, so the detection of infectious viruses is limited to laboratory studies using surrogate viruses, like PV and cell culture-adapted strains of HAV. Molecular methods for detecting the presence of enteric viruses lack the ability to differentiate infectious from inactivated viruses and are of limited value in studies on processing interventions (Richards 1999). This paper describes processing methods to reduce or eliminate enteric viruses in shellfish. Specific processing interventions include shellfish depuration and relaying, cooking and heat pasteurization, and high pressure processing. No review would be complete without a discussion of proper harvesting, storage, and handling practices to mitigate shellfish contamination. Recommendations are also provided on the need for new research directions to address shellfish-borne viruses.

\section{Virus Contamination of Shellfish}

\section{Harvesting}

Before considering processing interventions to eliminate enteric viruses from shellfish, one must consider prevention of contamination in the beginning. Common sense dictates the need to harvest shellfish from clean waters, but the determination of what constitutes clean waters is often difficult to discern. Europe subscribes to Escherichia coli standards under Regulations (EC) 852/2004, 853/2004 and 854/2004, which classifies shellfish based on tissue levels of bacteria under four classifications: class $A$, where shellfish may be directly sold without processing; class B, where shellfish must be depurated or relayed before marketing; class $\mathrm{C}$, where shellfish must be subjected to prolonged relay or cooking; and class D, where shellfish harvesting and distribution are prohibited (Anonymous 2004a, b and c). In the United States, 
sanitary surveys are performed on seawater from shellfish growing areas under the National Shellfish Sanitation Program Model Ordinance (Anonymous 1999), which classifies waters as approved, conditionally approved, restricted, or prohibited. Shellfish from approved beds may be marketed directly, those from conditionally approved and restricted areas must be processed according to an approved plan, and shellfish from prohibited areas may not be harvested or distributed. Fecal coliforms or E. coli limits serve as indicators of recent contamination events; however, shellfish, which are free from perceived bacterial contaminants may contain viruses, which can persist for longer periods than the indicator bacteria. Nevertheless, the first precaution in reducing shellfish-borne viral illnesses is to restrict shellfish harvesting in accordance with the applicable standards.

Handling

Improper post-harvest handling of shellfish can lead to product contamination and illness. Shellfish contamination may also come from the use of contaminated ice or water used in storing or rinsing products. Only potable water should be used in processing and for the preparation of ice, since ice has been epidemiologically linked to hepatitis A and NoV illnesses (Beller 1992; Khan et al. 1994). The shucking of shellfish offers another means of potential product contamination from the hands or gloves of shuckers or from the shucking knives, tabletops, or containers in which the shellfish are stored. Good sanitary practices are essential in reducing product contamination (Mokhtari and Jaykus 2009). Some shellfish dealers may subject shellfish to a process known as "freshening up" where previously harvested and stored shellfish are returned to the sea for a short period so that they may feed and be revived after a period out of water. This can lead to product contamination if the seawater that they are transplanted into is not clean. Freshening up is not an approved practice in the US or the EU, but has been known to occur. Shellfish handling and processing procedures should follow regulatory guidelines and good manufacturing practices, but strict adherence to these procedures may not be sufficient to eliminate all traces of virus contamination. There is no guarantee that shellfish or any other food item is absolutely safe, so risks must be minimized to the extent possible.

Localization within bivalve mollusks

Virus entry into molluscan shellfish is achieved by normal shellfish feeding activities, where the viruses are filtered from the water by the gills, and the filtered materials (viruses and associated solids) enter the digestive tract starting from the mouth. Once in the stomach and digestive diverticula, some viruses may pass through the shellfish and exit in the feces; however, some of the viruses are transported through the walls of the digestive tract into interior portions of the shellfish (Le Guyader et al., 2006; McLeod et al., 2009a). It has been suggested that the phagocytic process in hemocytes, which involves lysosomal enzymes, toxic oxygen intermediates, and antimicrobial peptides, may be responsible for killing bacteria in bivalves (Canesi et al., 2002), but this has not been demonstrated for human enteric viruses to date. Viruses are known to be retained by bivalves for significantly longer periods of time than bacterial indicators such as E. coli and fecal coliforms (Cook and Ellender 1986; Power and Collins 1989, 1990). Recombinant NoV (genogroup I) was shown, using immunohistochemical techniques, to be localized within the phagocytes and lumen of the digestive diverticula of the Pacific oyster, Crassostrea gigas, after 12 and $24 \mathrm{~h}$ of bioaccumulation (Le Guyader et al. 2006). Similarly, PV and NoV (genogroup II) were detected (using immunohistochemical techniques) in the lumen and within the stomach wall (stomach epithelium and digestive diverticula) of $C$. gigas when the oysters were fed these viruses for $48 \mathrm{~h}$ (Fig. 1) (McLeod et al. 2009a; Seamer 2007). PV and genogroup II NoV were seen in epithelial cells within the 
stomach wall of C. gigas after virus uptake for $48 \mathrm{~h}$ (arrows in Figs. 1A and 1D, respectively), compared to negative controls which lacked signal from PV (Figs. 1B and 1C) and from NoV (Fig 1E). NoV was also shown to be present in the digestive diverticula and stomach of the Asian oyster, Crassostrea ariakensis, after a $24 \mathrm{~h}$ bioaccumulation period (Wang et al. 2008). An in situ transcription and autoradiography technique revealed the presence of bioaccumulated HAV in the basal cells of the stomach epithelium in Eastern oysters, Crassostrea virginica (Romalde et al. 1994). Autoradiography also confirmed the presence of cricket paralysis virus (an insect picornavirus) in cells of the stomach epithelium, digestive diverticula, and intestine of C. gigas following virus uptake (Hay and Scotti 1986). Additional sites of virus localization are known and will be discussed elsewhere in this journal issue.

\section{Virus Inactivation in Shellfish: Processing Methods}

Washing and surface disinfection of shellfish may be effective in reducing post-harvest contamination, but most of the virus outbreaks associated with shellfish are from pre-harvest sources of contamination where the viruses are bioaccumulated within the tissues, as mentioned above. Since these viruses are internalized within the shellfish, they cannot be disinfected by traditional surface treatment, such as washing, exposure to UV light, or chemical disinfectants. The following section covers processing interventions, which likely reduce or in some cases eliminate infectious viruses within molluscan shellfish tissues.

\section{Shellfish Depuration}

The practice of shellfish depuration originated over a century ago (Herdman \& Scott 1896; Herdman \& Boyce 1899; Belding \& Lane 1909) and has significantly reduced the levels of shellfish-borne illnesses since its inception. Depuration is a commercial processing strategy where shellfish are placed in tanks of clean seawater and allowed to purge the contaminants over a period of several days (reviewed in Richards 1988, 1991). Figure 2 shows shellfish loaded into a commercial depuration tank before (Fig. 2A) and after (Fig. 2B) the addition of UV treated seawater. Water may be purified by replacement in what are termed flow-through systems, or using chlorine, ozone, or UV light (reviewed in Richards 1988, 1991). Studies have repeatedly shown that shellfish purge enteric viruses more slowly than most bacteria. Depuration is intended to reduce relatively low levels of contamination from shellfish and was never intended for highly contaminated products. In some cases, depurated shellfish have been associated with outbreaks of norovirus, hepatitis A, and other viral diseases (Grohmann et al. 1981; Ang 1998; Conaty et al. 2000; Le Guyader et al. 2008). Some outbreaks have been associated with contamination of product during the depuration process or from inadequate depuration controls (Guillois-Bécel et al. 2009; Richards 1988).

Pioneering research on the uptake and depuration of viruses concentrated on the use of PV and related enteroviruses (Liu et al. 1967a; Seraichekas et al. 1968; Di Girolamo et al. 1975; Metcalf et al. 1979). Studies showed that moderate levels of PV depurated within 3 days in Eastern oysters, C. virginica (Akin et al. 1966; Mitchell et al. 1966; Liu 1968; Hamblet et al. 1969; Meinhold \& Sobsey 1982; Sobsey et al. 1987; Power \& Collins 1989); Pacific oysters, C. gigas (Hoff \& Becker 1969); hard and soft shell clams, Mercenaria mercenaria and Mya arenaria (Liu et al. 1967a, 1967b). Hoff \& Becker (1969) showed that longer periods of depuration were required to eliminate PV from Manila clams, Tapes japonica, Tapes philippinarum and Olympia oysters, Ostrea lurida. Virus uptake in individual clams (M. mercenaria) varied by up to 100 -fold in controlled experiments, thus requiring longer depuration periods for more heavily contaminated individuals (Seraichekas et al. 1968). 
Hepatitis A virus is a major concern in some countries. In the late 1980's, a massive outbreak of HAV in China sickened nearly 300,000 consumers of contaminated clams (Halliday et al. 1991). In Italy, both infectious and RT-PCR-positive samples were identified in local and imported mussels (Mytilus galloprovincialis) that were non-depurated, as well as in mussels from Italy and Greece that were depurated (Chironna et al. 2002). Research undertaken in New Zealand demonstrated slow depuration of NoV from Pacific oysters that had been relayed to an uncontaminated growing area, with NoV still detectable by real time RT-PCR 8 weeks after contamination (Greening et al. 2003). However, there is a possibility that these results may have been confounded by potential recontamination of the oysters during the relaying period and the biological significance of these real time RT-PCR NoV positive results is unknown. HAV has been shown to persist in oysters for periods of up to 3 weeks in an infectious state and may be detected by PCR-based assays for 6 weeks (Kingsley and Richards 2003), indicating that relaying would have to be performed for periods longer than the industry practice in order to eliminate HAV. In contrast, mussels subjected to depuration for $96 \mathrm{~h}$ exhibited $98.7 \%$ and 97.0\% reductions in infectious HAV and rotaviruses, respectively (Abad et al. 1997). In two other studies on mussels, HAV persisted for 7 days (Enriquez et al. 1992), and at least 5 days (De Medici et al. 2001). Ueki et al. (2007) compared the persistence of human NoV and the surrogate FCV in the digestive diverticula of the oyster after depuration for 10 days and concluded that FCV was rapidly depleted, whereas NoV persisted. Persistence of NoV was determined by the detection of amplicon upon extraction and RT-PCR analysis. Using RT-PCR, Schwab et al. (1998) showed the presence of NoV within the digestive diverticula, stomach, adductor muscle and hemocytes of oysters, with only a 7\% reduction in NoV in the digestive diverticula after $48 \mathrm{~h}$ of depuration. Other studies showed high levels of HAV and NoV primarily within the gut and with lesser amounts internalized within non-digestive tissues (Romalde et al. 1994; Schwab et al. 1998; Le Guyader et al. 2006; McLeod et al. 2009a). NoV and HAV persisted in Pacific oysters after depuration for $23 \mathrm{~h}$, but a significant depletion of PV occurred in oysters over the same period (McLeod et al., 2009b). Loisy et al. (2005) showed that rotavirus virus-like particles persisted in oysters for 82 days as intact particles, but studies have not been performed to determine if wild-type or surrogate rotaviruses would retain their infectivity for this duration.

Depuration is a beneficial treatment to reduce bacterial contaminants from shellfish in a simulated natural environment, and can reduce virus levels in the process; however, depuration should not be relied on to reduce virus levels sufficiently for virus contaminated shellfish to be considered safe. This is because viruses, unlike bacteria, are generally infectious at very low levels, perhaps as low as 5 or 10 virus particles per meal. Thus, there is a need to reduce viruses to near negligible levels to improve the safety of shellfish.

\section{Relaying}

Another method to disinfect bivalve shellfish involves a longer-term purification process known as relaying (reviewed by Richards 1988). In relaying, shellfish are harvested from a contaminated area and transplanted to clean areas where they are broadcast on the ocean floor, or placed into containers, which are laid on the bottom or are suspended in racks or other devices for quick retrieval after the process is complete (Richards 1988). Where commercial depuration may be performed for only 2-3 days to meet regulatory requirements, relaying often requires 10 days or longer. Both depuration and relaying are generally acceptable for the depletion of bacterial contaminants, but appear insufficient for total enteric virus elimination. Very long-term relaying is a possible solution to the virus problem, if clean waters are available and if the cleanliness of the waters containing the shellfish can be maintained. This is a challenge, since: a) boats may illegally discharge waste in areas that were previously clean; $b$ ) changing winds, currents, and tides may carry polluted waters into harvesting areas; c) floods 
and storm water runoff may contaminate coastal waters; d) malfunctioning sewage treatment plants may allow the release of insufficiently treated effluent; and e) private septic systems may leach or overflow into coastal areas. Long-term relaying may be impractical from a commercial standpoint because of increased production costs associated with the additional handling and because it reduces product availability.

\section{Cooking and Heat Pasteurization}

The most effective method to reduce viruses from any food product is to cook the food thoroughly. In the case of shellfish, thorough cooking changes organoleptic characteristics and can toughen shellfish to an unpalatable state. Light cooking may be acceptable to some consumers, but is generally inadequate for the elimination of enteric viruses, since most of the viruses are inside the shellfish and would not be subjected to sufficient heat for their total inactivation. Shellfish affected by likely surface contamination, as might occur through handling or processing, could benefit from a quick cooking or blanching process. Local customs and preferences often dictate whether the product will be consumed raw or cooked. Heat pasteurization may be performed on in-shell or shucked products (Brown 1982; Goldmintz et al. 1983). In some countries, oysters are shucked, pasteurized, and refrigerated until sale and may be readily accepted in this form by some consumers. There remains a substantial portion of shellfish consumers who demand raw shellfish and for them alternate processing strategies, like high pressure processing may be desirable (see below).

Studies to evaluate the thermal resistance of viruses in foods, including molluscan shellfish, have given variable results, in part because of the use of different testing methods, different virus strains or surrogates, and different food compositions and shellfish species. Early studies using PV showed that virus inactivation rates in oysters (C. gigas and $O$. lurida) depended on the manner in which the oysters were cooked (fried, baked, stewed, or steamed) (DiGirolamo et al. 1970). Only a $2-\log _{10}$ decrease in viable viruses was seen after steaming for 30 min to an internal temperature of $93.7^{\circ} \mathrm{C}$. Virus survivals ranging from $7-13 \%$ were observed using different cooking methods (DiGirolamo et al. 1970). Hewitt and Greening (2006) showed differences in HAV and NoV inactivation in New Zealand greenshell mussels (Perna canaliculus) depending on the method of cooking, where boiling for 3 min was more effective than steaming for $3 \mathrm{~min}$ to inactivate HAV. In these studies, boiling for 3 min gave an internal temperature of $92^{\circ} \mathrm{C}$, but steaming for the same period gave an internal temperature of only $63^{\circ} \mathrm{C}$. Abad et al. (1997) also showed incomplete inactivation of HAV and rotavirus after steaming mussels for 3 min after the shells opened. Studies on meats and dairy products indicated that high protein and fat content protected PV and HAV from thermal inactivation (Bidawid et al. 2000; Filippi \& Banwart 1974); however, a recent study found that milk offered no protective effect for HAV, MNV-1, or human NoV (Hewitt et al. 2009). Total inactivation (5- $\left.\log _{10}\right)$ of MNV-1 was achieved in PBS after $3 \mathrm{~min}$ at $72^{\circ} \mathrm{C}$ (Wolf et al. 2009), but less thermal inactivation would be expected in viruses protected within shellfish tissues. Common sense would suggest that the manner and duration of cooking, as well as the final temperature achieved may be important to the inactivation of HAV, NoV, and other viruses. HAV and PV present in cockles were both shown to be reduced by $>4$ logs when an internal temperature of $90^{\circ} \mathrm{C}$ was maintained for $1 \mathrm{~min}$ (Millard et al. 1987). Similarly, heat inactivation processes $\left(90^{\circ} \mathrm{C}\right.$ for $90 \mathrm{sec}$ ) undertaken on shellfish products in processing establishments in the UK have been shown to be effective in inactivating NoV (as evidenced by a decrease in human illness resulting from the consumption of these products) (Lees 2000). Canned oysters are likely to be safe from a virus standpoint, since the canning process provides sufficient heat to essentially sterilize the product. It is unclear to what extent pasteurization is effective in virus elimination, but there are reports that $C$. botulinum spores resist the pasteurization process (Goldmintz et al. 1983; Chai et al. 1991). 
High Pressure Processing (HPP)

In recent years, HPP has emerged as a processing intervention to inactivate vibrios and spoilage bacteria in shellfish and to facilitate in the shucking of oysters. Commercial processors use around $275-300 \mathrm{MPa}$ of pressure for about 3 min to disinfect oysters. This non-thermal process produces shellfish, which have the taste and texture of raw product, remain plump and juicy, and have a slightly cooked appearance from partial denaturation of oyster proteins by the pressure treatment. In 2002, Kingsley and colleagues were the first to demonstrate the effectiveness of HPP to inactivate HAV and FCV (Kingsley et al. 2002). RNase protection assays showed that the pressure-treated viral capsids remained intact, since the virus RNA's were not degraded by RNase after pressure treatment (Kingsley et al. 2002). This led us to conclude that virus inactivation was likely from denaturation of virus capsid proteins, rather than from lysis of the virus capsid. Such denaturation would prevent the viruses from binding to host cells both in vivo and in vitro. Pressures of 250 and $450 \mathrm{MPa}$ for 5 min were sufficient to inactivate $7-\log _{10}$ of FCV and cell culture-adapted HAV, respectively, in culture media containing $10 \%$ fetal bovine serum (Kingsley et al. 2002). Different food matrices were expected to affect virus inactivation rates, as demonstrated for HAV where virus inactivation was affected by $\mathrm{pH}$, salt content, and temperature (Kingsley \& Chen 2009). High salt appeared to decrease the effectiveness of HPP in inactivating HAV and FCV (Kingsley \& Chen 2008; Grove et al. 2009). Oysters subjected to treatments of 350,375 , and $400 \mathrm{MPa}$ for 1 min showed reductions in HAV greater than 1,2 , and $3 \log _{10}$, respectively (Calci et al. 2005). Pressure oscillations did not significantly affect the inactivation of HAV in culture media; however, HAV was found to be more susceptible to inactivation when pressurization was performed at warmer temperatures (Kingsley et al. 2006). The advent of a quantitative assay for MNV-1, a closer relative of human NoV than FCV, led to a study showing a 4- $\log _{10}$ decrease in virus infectivity after pressure treatment of oysters for $5 \mathrm{~min}$ at $400 \mathrm{MPa}$ (Kingsley et al. 2007), therefore, it was uncertain which surrogate was more representative of human NoV inactivation under high pressure. Studies showed that PV could not be inactivated by pressures as high as $600 \mathrm{MPa}$, but that its close relative, HAV, was inactivated at substantially lower pressures (Kingsley et al. 2002). In addition, Aichi virus and coxsackievirus B5 were found to be resistant to $600 \mathrm{MPa}$ for 5 min, but human parechovirus- 1 and coxsackievirus $A 9$ were sensitive to $400 \mathrm{MPa}$, further demonstrating major differences in pressure response by closely related viruses (Kingsley et al. 2004).

Laboratory testing demonstrated the ability of HPP to inactivate HAV and NoV surrogates. The next question was whether HPP could inactivate human NoV from which we might gain insight as to what was the better surrogate, FCV or MNV-1. A collaborative study was initiated between the U.S. Department of Agriculture in Dover, DE; Virginia Polytechnic and State University in Blacksburg, VA; and Emory University in Atlanta, GA to conduct a human challenge study to assess the effectiveness of HPP to inactivate human NoV in oysters (manuscript in preparation). Over 50 volunteers were challenged either with oysters that were inoculated into their stomach cavity with NoV and pressure-treated or with oysters that were similarly inoculated with virus but were not pressure treated. We used safety-tested genogroup I, cluster 1 Norwalk virus, which was obtained from a previous volunteer study. Results indicate that human NoV in oysters is more resistant to HPP than either FCV or MNV-1, which again stresses the limited usefulness of studies involving surrogate viruses. It is possible that each of the $\mathbf{3 0}$ or so genetic clusters of NoV may have unique sensitivities to HPP, with some clusters more sensitive to the effects of processing temperature, salt concentration, or matrix composition. Pressure sensitivity may also differ between viruses within the same cluster, much like HAV sensitivities vary among cell culture-adapted strains (Shimasaki et al. 2009). Such is the state-of-the-art, with some successes, some failures, and some uncertainty. 


\section{Irradiation}

Enteric virus inactivation studies have included work on the effects of ultraviolet light and ionization radiation on virus levels. Ultraviolet irradiation is effective in reducing NoV surrogates and HAV on the surface of product, but does not have penetrating power to inactivate viruses deep within the shellfish. UV irradiation at $120 \mathrm{~J} / \mathrm{m}^{2}$ and $200 \mathrm{~J} / \mathrm{m}^{2}$ reduced the infectivity of FCV and a presumed canine calicivirus by $3-\log _{10}$, respectively, while $650 \mathrm{~J} / \mathrm{m}^{2}$ was required to reduce MS2 phage counts by the same amount (de Roda Husman, et al. 2004). In PBS, MNV1 was readily inactivated by UV; however, the amount of UV exposure was not reported (Wolf et al. 2009). Ionizing radiation was used to inactivate PV in shucked and in-shell oysters (C. gigas and O. lurida), but the levels required to inactivate $90 \%$ of the viruses imparted undesirable organoleptic qualities, rendering the shellfish unpalatable (Di Girolamo et al. 1972). Jung and coworkers (2009) showed the $\mathrm{D}_{10}$ value for PV at $2.94 \mathrm{kGy}$, and referred to PV as a surrogate for NoV (Jung et al. 2009). Gamma irradiation of clams (M. mercenaria) showed poor reduction of F-coliphage, where the mean $D_{10}$ value was $13.5 \mathrm{kGy}$ and where $>0.5 \mathrm{kGy}$ was reportedly lethal to the shellfish (Harewood et al. 1994). HAV and rotavirus were eliminated from oysters (C. virginica) and clams (M. mercenaria) at $\mathrm{D}_{10}$ values of 2.0 and $2.4 \mathrm{kGy}$, respectively (Mallet et al. 1991). These authors reported that at these levels of irradiation, shellfish survival rates and organoleptic characteristics were relatively unaffected. Gamma irradiation at $0.5,0.3$, and 0.1 kGy produced $3-\log _{10}$ decreases in FCV, canine norovirus, and MS2 titers, respectively, in low protein solutions, but high amounts of protein appreciably reduced the effectiveness of ionizing irradiation (de Roda Husman et al. 2004). Some consumers have expressed uncertainty about the safety of irradiated foods; however, education about the food benefits of irradiation is likely to improve consumer perceptions. The variability in the results among the studies may be attributed, in part, to the use of different viruses, shellfish species, exposure methods, and matrix compositions. Further studies on the effectiveness of irradiation to inactivate human enteric viruses are warranted.

\section{Freezing}

Freezing of shellfish is a potential processing method of limited value. Raw shellfish meats are often frozen to await subsequent processing, such as breading or cooking either at the restaurant or at home. Although freezing tends to preserve viruses, there can be an initial loss in virus titer with each freeze-thaw cycle. That loss in titer may reduce virus levels in minimally contaminated product to enhance safety. Studies on PV survival in oysters under frozen conditions showed an approximately $1-\log _{10}$ decrease in infectious viruses after storage for 4 to 12 weeks at $-17.5^{\circ} \mathrm{C}$ (Di Girolamo et al. 1970). We suspect that this decrease occurs during the freezing and thawing process, rather than as a result of the duration of frozen storage. In our laboratory, we see an approximately $10 \%$ decrease in NoV titer (based on RT-PCR assay) for each round of freezing and thawing, suggesting that freezing and thawing may cause lysis of the viral capsids (G. Richards, unpublished). We have NoV stool samples that have been frozen for 20 years and still maintain high NoV titers (as high as $6.16 \times 10^{10} / \mathrm{g}$ of stool by RTPCR), since they have not been repeatedly frozen and thawed (Richards et al. 2004). Freezing by itself seems inadequate to protect the consumer from even lightly contaminated shellfish, but when freezing is combined with cooking or HPP, the additive effect of both processes would further enhance shellfish safety.

\section{Smoking}

Smoking is another commercial method of processing shellfish. There are various, nonstandardized methods for smoking shellfish and the amount of heat applied in this process is 
likely to vary considerably from one facility to another and perhaps from one batch of shellfish to another. It is uncertain if smoking alone is effective in reducing virus levels in shellfish, but many smoked products are also canned, which provides sufficient heat to inactivate viruses. Outbreaks of Listeria monocytogenes have been associated with smoked mussels (Brett et al. 1998; Baek et al. 2000), so it seems likely that HAV and NoV would also survive some smoking processes unless the product was canned after smoking.

Other Techniques

A report by Mormann et al. (2009) claimed that cooling, freezing, acidification, and pasteurization were ineffective in inactivating NoV. We would temper that claim somewhat, as some losses in viral infectivity might occur for cooling and freezing, but not at the levels desirable for a food processing intervention. In fact. cooling of viruses tends to preserve viruses and would not be expected to exert a major role in reducing virus titers. Likewise, enteric viruses are accustomed to the acidic environment of the human gut and are, therefore, acid resistant, except at very low pH's (e.g., < pH 3.0). Mussels subjected to the marinade process were reported to retain NoV and HAV after 4 weeks at pH's as low as 3.75, but FCV was readily inactivated by the low pH (Hewitt \& Greening 2004). The determination of NoV and HAV infectivity in that study was based on RT-PCR, which as previously stated, is not a good indicator for virus infectivity. Finally, there is some evidence to suggest that virus titers are reduced with drying/desiccation, which may be applicable to viruses on the surface of processing equipment. Although dehydrated shellfish are not a widely known commercial product, there are reports that oysters have been freeze dried, placed into capsules, and marketed as health foods in New Zealand.

\section{Recommendations}

This paper does not provide any magical treatment or process to inactivate viruses from shellfish, only methods that may help reduce the levels of viral pathogens. Industry needs to use common sense in the harvesting, handling, and processing of shellfish. The shellfish industry can benefit from abiding by harvesting regulations and by implementing their own simple precautions on the handling of shellfish, particularly those destined for raw consumption. Industry must follow good manufacturing practices in preventing process-induced contamination of shellfish. Processes like long-term relaying or HPP may be good alternatives to enhance shellfish safety from both a viral and bacterial standpoint, while accommodating consumer demands for raw product. Shellfish relaying and HPP offer the benefit of reducing, but not necessarily eliminating, infectious virus particles, which infect humans at very low concentrations. We recommend the use of combined processing technique, such as: a) shellfish relaying followed by HPP; b) pasteurization followed by freezing; or c) depuration followed by moderate cooking, since multiple methods have an additive advantage in reducing viral contamination. Since most processing methods can not guarantee the safety of shellfish or any other food for that matter, the questions become, what is the acceptable level of risk for viruses in shellfish and what tests do we use to monitor virus levels? Clearly, there are problems regulating an industry based on the use of indicator organisms for the detection of specific pathogens using methods, which cannot discriminate between infectious and inactivated viruses (Richards 1999). These are some of the challenges the industry and regulators must address in order to satisfy consumer demands for highly prized shellfish. Today more than ever before, viral illnesses threaten the welfare of the shellfish industry and associated trades. It is incumbent upon regulators, shellfishermen, handlers, processors, the restaurant and tourist trades, and consumers to join forces to reduce the risk of shellfish-borne 
illnesses in support of continued marketability of shellfish products. Until cell culture propagation methods become available to quantify infectious NoV, HAV, and other viral pathogens, researchers must support efforts to improve shellfish safety by evaluating the effectiveness and limitations of processing techniques, surrogate viruses, and analytical methods.

We recommend that presumptive information derived from the use of surrogates and RT-PCR be subjected to proof-of-principle testing and validated in volunteer studies using the pathogens themselves. Human challenge studies are essential to determine which processing techniques are effective in reducing NoV in shellfish and other foods. This recommendation will be controversial, since funding for surrogate research has been plentiful and many researchers (including ourselves) are accustomed to conducting NoV research with virus surrogates. However, a shift in funding priorities is essential if we are to identify realistic and practical processing strategies to improve the overall safety of shellfish.

\section{References}

Abad, F. X., Pintó, R. M., Gajardo, R., \& Bosch, A. (1997). Viruses in mussels: public health implications and depuration. Journal of Food Protection, 60, 677-681.

Akin, E. W., Hamblet, F. E., \& Hill, W. F. Jr. (1966). Accumulation and depuration of poliovirus by individual oysters. Gulf Coast Shellfish Sanitation Research Center, Dauphin Island, Alabama. Technical memorandum GCSSRC-FY66-5, 5 pp.

Ang, L. H. (1998). An outbreak of viral gastroenteritis associated with eating raw oysters. Communicable Disease and Public Health, 1, 38-40.

Anonymous. (1999). National Shellfish Sanitation Program Model Ordinance IV. Shellstock growing areas. Department of Health and Human Services, U.S. Food and Drug Administration, Washington, DC.

Anonymous. (2004a). Regulation (EC) No 852/2004. On the Hygiene of Foodstuffs. Official Journal of the European Union, L139/1, 1-54.

Anonymous. (2004b). Regulation (EC) No 853/2004. Laying down specific hygiene rules for food of animal origin. Official Journal of the European Union, L139/55, 55-151.

Anonymous. (2004c). Regulation (EC) No 854/2004. Laying down specific rules for the organisation of official controls on products of animal origin intended for human consumption. Official Journal of the European Union, L155/206.

Bae, J., \& Schwab, K. J. (2008). Evaluation of murine norovirus, feline calicivirus, poliovirus, and MS2 as surrogates for human norovirus in a model of viral persistence in surface water and groundwater. Applied and Environmental Microbiology, 74, 477-484.

Baek, S. Y., Lim, S. Y., Lee, D. H., Min, K. H., \& Kim, C. M. (2000). Incidence and characterization of Listeria monocytogenes from domestic and imported foods in Korea. Journal of Food Protection, 63, 186-189. 
Belding, D. L., \& Lane, F. C. (1909). The shellfisheries of Massachusetts: their present condition and extent. In A Report Upon the Mollusk Shellfisheries of Massachusetts. Boston: Wright \& Potter.

Beller, N. (1992). Hepatitis A outbreak in Anchorage, Alaska, traced to ice slush beverages. Western Journal of Medicine, 156, 624-627.

Belliot, G., Lavaux, A., Souihel, D., Agnello, D., \& Pothier, P. (2008). Use of murine norovirus as a surrogate to evaluate resistance of human norovirus to disinfectants. Applied and Environmental Microbiology, 74, 3315-3318.

Bidawid, S., Farber, J. M., Satter, S. A., \& Hayward, S. (2000). Heat inactivation of hepatitis A virus in dairy foods. Journal of Food Protection, 63, 522-528.

Brett, M. S., Short, P., \& McLauchlin, J. (1998). A small outbreak of listeriosis associated with smoked mussels. International Journal of Food Microbiology, 43, 223-229.

Brown, J.W. (1982). Economic analysis of "steam-shock" and "pasteurization" processes for oyster shucking. Marine Fisheries Review, 44, 21-25.

Cacopardo, B., Russo, R., Preiser, W., Benanti, F., Brancati, F., \& Nunnari, A. (1997). Acute hepatitis E in Catania (eastern Sicily) 1980-1994. The role of hepatitis E virus. Infection, 25, 313-316.

Calci, K. R., Meade, G. K., Tezloff, R. C., \& Kingsley, D. H. (2005). High-pressure inactivation of hepatitis A virus within oysters. Applied and Environmental Microbiology, 71, 339-343.

Canesi, L., Gallo, G., Gavioli, M., \& Pruzzo, C. (2002). Bacteria-hemocyte interactions and phagocytosis in marine bivalves. Microscopy Research and Technique, 57, 469-476.

Cannon, J. L., Papafragkou, E., Park, G. W., Osborne, J., Jaykus, L. A., \& Vinjé, J. (2006). Surrogates for the study of norovirus stability and inactivation in the environment: a comparison of murine norovirus and feline calicivirus. Journal of Food Protection, 69, 2761-2765.

Chai, T., Liang, K. T., Pace, J., \& Schlimme, D. V. (1991). Effect of heat processing on quality of pasteurized oysters. Journal of Food Science, 56, 1292-1294.

Chironna, M., Germinario, C., De Medici, D., Fiore, A., Di Pasquale, S., Quarto, M., \& Barbuti, S. (2002). Detection of hepatitis A virus in mussels from different sources marketed in Puglia region (South Italy). International Journal of Food Microbiology, 75, 11-18.

Conaty, S., Bird, P., Bell, G., Kraa, E., Grohmann, G., \& McAnulty, J. M. (2000). Hepatitis A in New South Wales, Australia from consumption of oysters: the first reported outbreak. Epidemiology and Infection, 124, 121-130.

Cook, D. W. \& Ellender, R. D. (1986). Relaying to decrease the concentration of oysterassociated pathogens. Journal of Food Protection, 49, 196-202.

Dawson, D. J., Paish, A., Staffell, L. M., Seymour, I. J., \& Appleton, H. (2005). Survival of viruses on fresh produce, using MS2 as a surrogate for norovirus. Journal of Applied Microbiology. 98, 203-209. 
De Medici, D., Ciccozzi, M., Foire, A., Di Pasquale, S., Parlato, A, Ricci-Bitti, P., \& Croci, L. (2001). Closed-circuit system for the depuration of mussels experimentally contaminated with hepatitis A virus. Journal of Food Protection, 64, 877-880.

de Roda Husman, A. M., Bijkerk, P., Lodder, W., van den Berg, H., Pribil, W., Cabaj, A., Gehringer, P., Sommer, R., \& Duzier, E. (2004). Calicivirus inactivation by nonionizing (253.7nanometer-wavelength [UV]) and ionizing (gamma) radiation. Applied and Environmental Microbiology, 70, 5089-5093.

DiGirolamo, R., Liston, J., \& Matches, J. (1970). Survival of virus in chilled, frozen, and processed oysters. Applied Microbiology, 20, 58-63.

Di Girolamo, R., Liston, J., \& Matches, J. (1972). Effects of irradiation on the survival of virus in West Coast oysters. Applied Microbiology, 24, 1005-1006.

Di Girolamo, R., Liston, J., \& Matches, J. (1975). Uptake an elimination of poliovirus by West Coast oysters. Applied Microbiology, 29, 260-264.

Doultree, J. C., Druce, J. D., Birch, C. J., Bowden, D. S., \& Marshall, J. A. (1999). Inactivation of feline calicivirus, a Norwalk virus surrogate. Journal of Hospital Infection, 41, 51-57.

Enriquez, R., Frösner, G.G., Hochstein-Mintzel, V., Riedemann, S., \& Reinhardt, G. (1992). Accumulation and persistence of hepatitis A virus in mussels. Journal of Medical Virology, 37, 174-179.

Filppi, J. A., \& Banwart, G. J. (1974). Effect of the fat content of ground beef on the heat inactivation of poliovirus. Journal of Food Science, 39, 865-868.

Goldmintz, D., Babinchak, J.A., Richards, G.P., \& Graikoski, J.T. (1983). Bacteriological evaluation of steam pasteurized oysters, Crassostrea virginica. Developments in Industrial Microbiology, 24, 457-466.

Greening, G., Hewitt, J., Hay, B. E., \& Grant, C. M. (2003). Persistence of Norwalk-like viruses over time in Pacific oysters grown in the natural environment. In A. Villalba, B. Reguera, J. L. Romalde, \& R. Beiras (Eds.), Proceedings of the $4^{\text {th }}$ International Conference on Molluscan Shellfish Safety pp. 367-377. Conselleria de Pesca e Asuntos Maritimos da Xunta de Galacia and Intergovernmental Oceanographic Commission of UNESCO, Santiago de Compostela, Spain.

Grohmann, G. S., Murphy, A. M., Christopher, P. J., Auty, G., \& Greenberg, H. B. (1981). Norwalk virus gastroenteritis in volunteers consuming depurated oysters. Australian Journal of Experimental Biology \& Medical Science, 59, 219-228.

Grove, S. F., Lee, A., Stewart, C. M., \& Ross, T. (2009). Development of a high pressure processing inactivation model for hepatitis A virus. Journal of Food Protection, 72, 1434-1442.

Guillois-Bécel, Y., Couturier, E., Le Saux, J. C., Roque-Afonso, A. M., Le Guyader, F. S., Le Goas, A., et al. (2009). An oyster-associated hepatitis A outbreak in France in 2007. Eurosurveillance, 14, 1-6. 
Halliday, M. L., Kang, L. Y., Zhou, T. K., Hu, M. D., Pan, Q. C., Fu, T. Y., et al. (1991). An epidemic of hepatitis $A$ attributable to the ingestion of raw clams in Shanghi, China. Journal of Infectious Diseases, 164, 852-859.

Hamblet, F. E., Hill, W. F. Jr., Akin, E. W., \& Benton, W. H. (1969). Oysters and human viruses: effects of seawater turbidity, on poliovirus uptake and elimination. American Journal of Epidemiology, 89, 562-571.

Harewood, P., Rippey, S., \& Montesalvo, M. (1994). Effect of gamma irradiation on shelf life and bacterial and viral loads in hard-shelled clams (Mercenaria mercenaria). Applied and Environmental Microbiology, 60, 2666-2670.

Hay, B. E., \& Scotti, P. (1986). Evidence for intracellular absorption of virus by the Pacific oyster, Crassostrea gigas. New Zealand Journal of Marine and Freshwater Research, 20, 655659.

Herdman, W. A., \& Boyce, R. (1899). Oysters and disease. An account of certain observations upon the normal and pathological history and bacteriology of the oyster and other shellfish. Lancashire Sea-Fisheries Memoir No. 1, London, pp. 35-40.

Herdman, W. A., \& Scott, A. (1896). Report on the investigations carried out in 1895 in connection with the Lancashire Sea-Fisheries Laboratory at the University College, Liverpool. Proceedings Trans. Liverpool Biological Society, 10, 103-174.

Hewitt, J., \& Greening, G. E. (2004). Survival and persistence of norovirus, hepatitis A virus, and feline calicivirus in marinated mussels. Journal of Food Protection, 67, 1743-1750.

Hewitt, J., \& Greening, G. E. (2006). Effect of heat treatment on hepatitis A virus and norovirus in New Zealand greenshell mussels (Perna canaliculus) by quantitative real-time reverse transcription PCR and cell culture. Journal of Food Protection, 69, 2217-2223.

Hewitt, J., Rivera-Aban, M., \& Greening, G. E. (2009) Evaluation of murine norovirus as a surrogate for human norovirus and hepatitis $A$ virus in heat inactivation studies. Journal of Applied Microbiology, 107, 65-71.

Hoff, J. C., \& Becker, R. C. (1969). The accumulation and elimination of crude and clarified poliovirus suspensions by shellfish. American Journal of Epidemiology, 90, 53-61.

Jung, P-M., Park, J. S., Park, J-G., Park, J-N, Han, I-J, Song, B-S, et al. (2009). Radiation sensitivity of poliovirus, a model for norovirus, inoculated in oyster (Crassostrea gigas) and culture broth under different conditions. Radiation Physics and Chemistry, 78, 597-599.

Kingsley, D. H., \& Chen, H. (2008). Aqueous matrix composition and pH influence feline calicivirus inactivation by high pressure processing. Journal of Food Protection, 71, 1598-1603.

Kingsley, D. H, \& Chen, H. (2009). Influence of $\mathrm{pH}$, salt, and temperature on pressure inactivation of hepatitis A virus. International Journal of Food Microbiology, 130, 61-64.

Kingsley, D. H., Chen, H., \& Hoover, D. G. (2004). Inactivation of selected picornaviruses by high hydrostatic pressure. Virus Research, 102, 221-224. 
Kingsley, D. H., Guan, D., Hoover, D. G., \& Chen, H. (2006). Inactivation of hepatitis A virus by high-pressure processing: the role of temperature and pressure oscillation. Journal of Food Protection, 69, 2454-2459.

Kingsley, D. H., Holliman, D. R., Calci, K. R., Chen, H., \& Flick, G. J. (2007). Inactivation of a norovirus by high-pressure processing. Applied and Environmental Microbiology, 73, 581-585.

Kingsley, D. H., Hoover, D. G., Papafragkou, E., \& Richards, G. P. (2002). Inactivation of hepatitis A virus and a calicivirus by high hydrostatic pressure. Journal of Food Protection, 65, 1605-1609.

Kingsley, D. H., \& Richards, G. P. (2003). Persistence of hepatitis A virus in oysters. Journal of Food Protection, 66, 331-334.

Khan, A. S., Moe, C. L., Glass, R. I., Monroe, S. S., Estes, M. K., Chapman, L. E., et al. (1994). Norwalk virus-associated gastroenteritis traced to ice consumption aboard a cruise ship in Hawaii: comparison and application of molecular method-based assays. Journal of Clinical Microbiology, 32, 318-322

Lees, D. (2000). Viruses and bivalve shellfish. International Journal of Food Microbiology, 59, 81-116.

Le Guyader, F. S., Loisy, F., Atmar, R. L., Hutson, A. M., Estes, M. K., Ruvoen, N., Pommepuy, M., \& Le Pendu, J. (2006). Norwalk virus-specific binding to oyster digestive tissues. Emerging Infectious Diseases, 12, 931-936.

Le Guyader, F. S., Le Saux, J. C., Ambert-Balay, K., Krol, J., Serais, O., Parnaudeau, S., et al. (2008). Aichi virus, notovirus, astrovirus, enterovirus, and rotavirus involved in clinical cases from a French oyster-related gastroenteritis outbreak. Journal of Clinical Microbiology, 46, 40114017.

Liu, O. C. 1968. Appraisal and planning of virus research program. Northeast Shellfish Sanitation Research Center, U.S. Public Health Service, Narragansett, Rhode Island, 38 pp.

Liu, O. C., Seraichekas, H. R., \& Murphy, B. L. (1967a). Viral pollution and self-cleansing mechanisms of hard clams. In G. Berg (Ed.). Transmission of Viruses by the Water Rout. (pp. 419-437). New York: Interscience Publishers

Liu, O. C., Seraichekas, H. R., \& Murphy, B. L. (1967b). Viral depuration of the Northern quahaug. Applied Microbiology, 15, 307-315.

Loisy, F., Atmar, R. L., Le Saux, J. C., Cohen, J., Caprais, M. P., Pommepuy, M., \& Le Guyader, F. S. (2005). Use of rotavirus virus-like particles as surrogates to evaluate virus persistence in shellfish. Applied and Environmental Microbiology, 71, 6049-6053.

Mallet, J. C., Beghian, L. E., Metcalf, T. G., \& Kaylor, J. D. (1991). Potential of irradiation technology for improved shellfish sanitation. Journal of Food Safety, 11, 231-245.

McLeod, C., Hay, B., Grant, C., Greening, G., \& Day, D. (2009a). Localization of norovirus and poliovirus in Pacific oysters. Journal of Applied Microbiology, 106, 1220-1230. 
McLeod, C., Hay, B., Grant, C., Greening, G., \& Day, D. (2009b). Inactivation and elimination of human enteric viruses by Pacific oysters. Journal of Applied Microbiology, (in press).

Meinhold, A. F., \& Sobsey, M. D. (1982). The uptake, elimination and tissue distribution of poliovirus in the American oyster, Crassostrea virginica. Abstracts of the Annual Meeting of the American Society for Microbiology. p. 181.

Metcalf, T. G., Mullin, B., Eckerson, D., Moulton, E., \& Larkin, E. P. (1979). Bioaccumulation and depuration of enteroviruses by the soft-shelled clam, Mya arenaria. Applied and Environmental Microbiology, 38, 275-282.

Millard, J., Appleton, H., \& Parry, J. V. (1987). Studies on heat inactivation of hepatitis A virus with special reference to shellfish. Part 1. Procedures for infection and recovery of virus from laboratory-maintained cockles. Epidemiology and Infection, 98, 397-414.

Mitchell, J. R., Presnell, M. W., Akin, E. W., Cummings, J. M., \& Liu, O. C. (1966). Accumulation and elimination of poliovirus by the Eastern oyster. American Journal of Epidemiology, 84, 4050 .

Mokhtari, A. \& Jaykus, L. A. (2009). Quantitative exposure model for the transmission of norovirus in retail food preparation. International Journal of Food Microbiology, 133, 38-47.

Mormann, S., Dabisch, M., \& Becker, B. (2009). Effects of technological processes on the tenacity and inactivation of norovirus GGII in experimentally contaminated foods. Applied and Environmental Microbiology (in press).

Nakagawa-Okamoto, R., Arita-Nishida, T., Todo, S., Kato, H., Iwata, H., Akiyama, M., et al. (2009). Detection of multiple sapovirus genotypes and genogroups in oyster-associated outbreaks. Japanese Journal of Infectious Diseases, 62, 63-66.

Nuanualsuwan, S., Mariam, T., Himathongkham, S., \& Cliver, D. O. (2002). Ultraviolet inactivation of feline calicivirus, human enteric viruses and coliphages. Photochemistry and Photobiology, 76, 406-410.

Power, U. F., \& Collins, J. K., (1989). Differential depuration of poliovirus, Escherichia coli, and a coliphage by the common mussel, Mytilus edulis. Applied and Environmental Microbiology, 55, 1386-1390.

Power, U. F. and Collins, J. K., (1990). Tissue distribution of a coliphage and Escherichia coli in mussels after contamination and depuration. Applied and Environmental Microbiology, 56, 803807.

Richards, G. P. (1988). Microbial purification of shellfish: a review of depuration and relaying. Journal of Food Protection, 51(3), 218-251.

Richards, G. P. (1991). Shellfish depuration, Ch. 16. In D. R. Ward \& C.R. Hackney (Eds.), Microbiology of Marine Food Products (pp. 395-428). New York: Van Nostrand Reinhold.

Richards, G. P. (1999). Limitations of molecular biological techniques for assessing the virological safety of foods. Journal of Food Protection, 62, 691-697. 
Richards, G. P., Watson, M. A., \& Kingsley, D. H. (2004). A SYBR green, real-time RT-PCR method to detect and quantitate Norwalk virus in stools. Journal of Virological Methods, 116, 6370.

Romalde, J. L., Estes, M. K., Szücs, G., Atmar, R. L., Woodley, C. M., \& Metcalf, T. G. (1994). In situ detection of hepatitis A virus in cell cultures and shellfish tissues. Applied and Environmental Microbiology, 60, 1921-1926.

Schwab, K. J., Neill, F. H., Estes, M. K., Metcalf, T. G., \& Atmar, R. L. (1998). Distribution of Norwalk virus within shellfish following bioaccumulation and subsequent depuration by detection using RT-PCR. Journal of Food Protection, 61, 1674-1680.

Seamer, C. (2007). The Biology of Virus Uptake and Elimination by Pacific Oysters (Crassostrea gigas). School of Biological Sciences. Wellington, Victoria University of Wellington. PhD Thesis, pp. 239.

Seraichekas, H. R., Brashear, D.A., Barnick, J. A., Carey, P. F., \& Liu, O. C. (1968). Viral depuration by assaying individual shellfish. Applied Microbiology, 16, 1865-1871.

Shimasaki, N., Kiyohara, T., Totsuka, A., Nojima, K., Okada, Y., Kajioka, J., et al. (2009). Inactivation of hepatitis $A$ virus by heat and high hydrostatic pressure: variation among laboratory strains. Vox Sanguinis, 96, 14-19.

Sobsey, M. D., Davis, A.L., \& Rullman, V. A. (1987). Persistence of hepatitis A virus and other viruses in depurated Eastern oysters. Proceedings Oceans '87, 5, 1740-1745.

Tomar, B. S. (1998). Hepatitis E in India. Zhonghua Min Guo Xiao Er Ke Yi Xue Hui Za Zhi, 39, 150-156.

Ueki, Y., Shoji, M., Suto, A., Tanabe, T., Okimura, Y., Kikuchi, Y., et al. (2007). Persistence of calicivirus in artificially contaminated oysters during depuration. Applied and Environmental Microbiology, 73, 5698-5701.

Wang, D., Wu, Q., Kou, X., Yao, L., Zhang, J. (2008). Distribution of norovirus in oyster tissues. Journal of Applied Microbiology, 105, 1966-1972.

Wolf, S., Rivera-Aban, M., \& Greening, G. E. (2009). Long-range reverse transcription as a useful tool to assess the genomic integrity of norovirus. Food and Environmental Virology, 1, 129-136. 


\section{Figures}

Figure 1. Localization of poliovirus (PV, panels A, B, and C) and genogroup II norovirus (NoV, panels $D$ and $E$ ) (using immunohistochemical techniques) in the stomach epithelium of Pacific oysters (Crassostrea gigas) which had bioaccumulated virus for $48 \mathrm{~h}$. Panels $A$ and $D$ show staining of PV- and NoV-contaminated oysters, respectively. Arrows point to PV (A) or NoV (D) immunoreactivity within epithelial cells of the stomach wall. Panels $B$ and $E$ show staining of uninfected oysters (negative controls) for $\mathrm{PV}$ and NoV respectively. Panel $\mathrm{C}$ is a control showing the staining pattern of a PV-contaminated oyster in which the primary antibody was omitted. PV immunoreactivity was detected using an anti-DIG rhodamine conjugate (red). NoV immunoreactivity was detected with an anti-goat AlexaFluor 488 (green) conjugate (Molecular Probes, Oregon, USA). Cell nuclei are counterstained with DAPI (blue) (panels A, B, and C) or propidium iodide (red) ( $D$ and $E$ ). Panels $A, B$ and $C$ are overlaid with a dual image taken using the FITC channel (green) to allow tissue morphology to be visualized using background autofluorescence. Scale bars are $100 \mu \mathrm{m}$. Abbreviations: CT, connective tissue; L, lumen; SW, stomach wall.

Figure 2. Shellfish undergoing depuration at a facility in Newburyport, Massachusetts. A) Containers of shellfish with wire mesh on the bottoms are placed into tanks. B) Tanks are filled with UV-irradiated seawater which is recirculated for usually 3 days. 


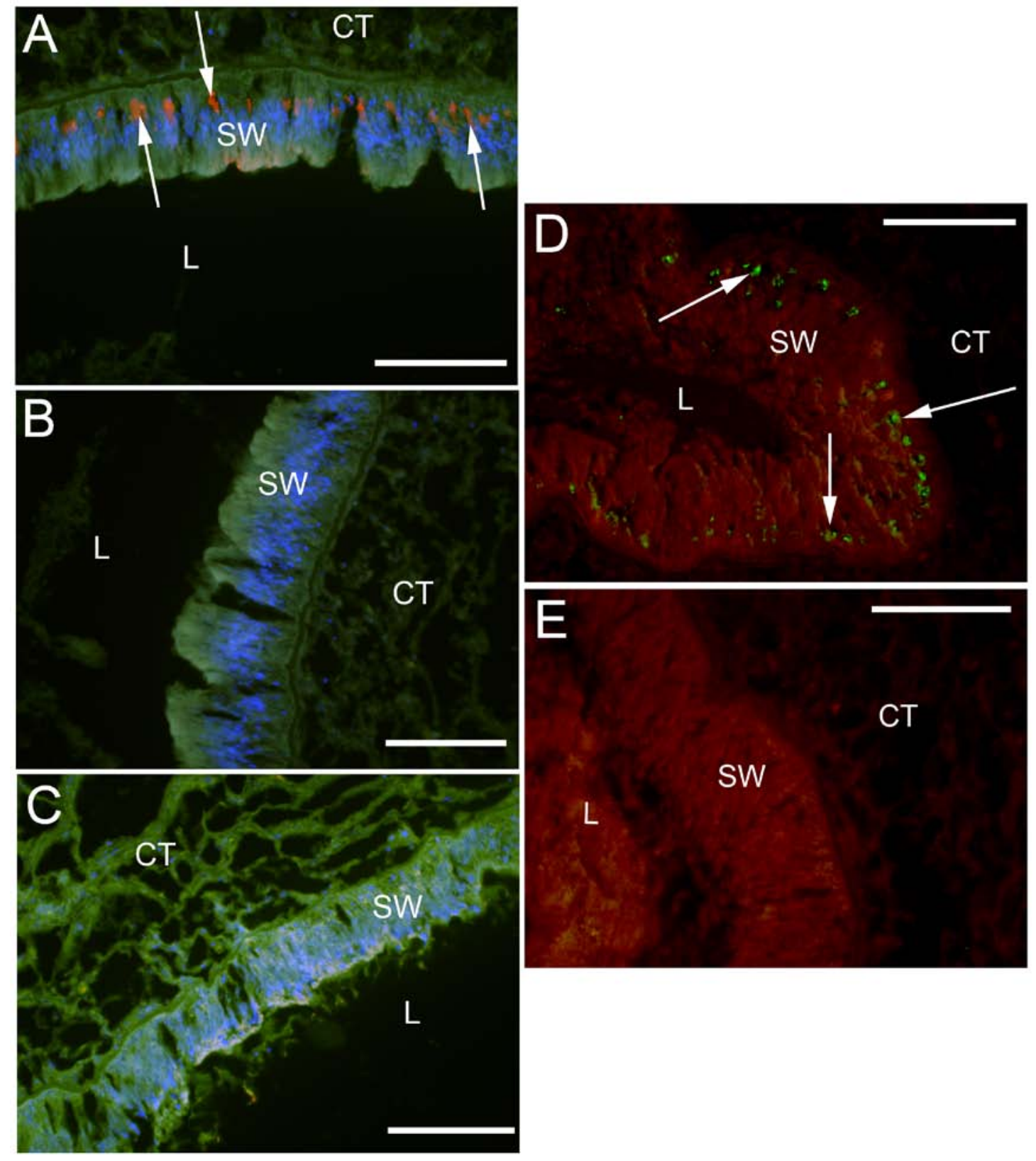

Figure 1 
A

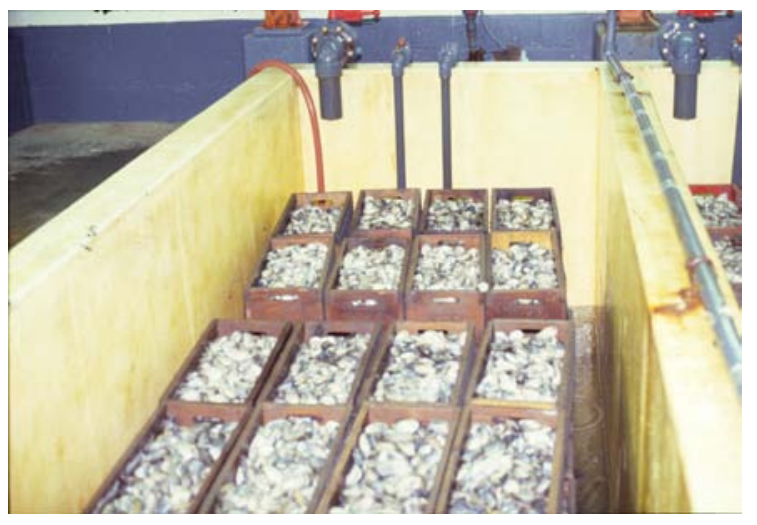

B

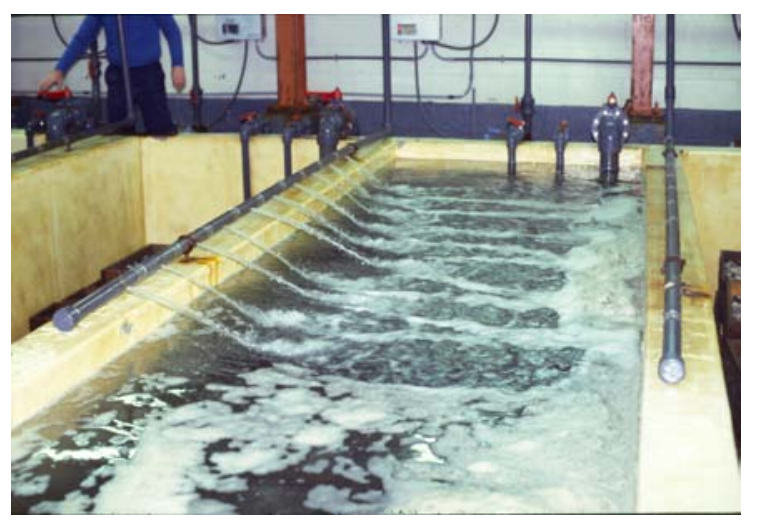

Figure 2 